\title{
CARTAS DE LEITORES COMO ESPAÇOS PRIVILEGIADOS DE APROPRIAÇÃO DA INFORMAÇÃO E DOS EFEITOS DE SENTIDO
}

\section{READER'S LETTERS AS PRIVILEGED SPACES OF APPROPRIATION OF INFORMATION AND THE MEANING EFFECTS}

Tamara de Souza Brandão Guaraldoa

\begin{abstract}
RESUMO
Introdução: Este artigo debate o conceito de apropriação da informação apoiado em pesquisa bibliográfica e discussão crítica de trabalhos publicados sobre a seção cartas de leitores de jornais impressos. Nas seguintes bases de dados da internet: Scielo, Google Acadêmico e portal BRAPCI, nas quais foram selecionados treze trabalhos científicos em português com o descritor "cartas de leitores" e que apresentaram dados de pesquisa aplicada, pertinentes à abordagem deste estudo. Objetivo: Discutir o conceito de apropriação da informação apoiado no estudo bibliográfico e análise crítica de trabalhos publicados sobre a seção cartas de leitores. Metodologia: Pesquisa bibliográfica sobre as cartas de leitores e discussão dos artigos selecionados sob o viés analítico dos efeitos de sentido e elementos da análise do discurso. Resultados: Identificam-se nas pesquisas estudadas, as cartas de leitores como espaços privilegiados dentro dos meios de informação impressos para os estudos de apropriação da informação, já que se constituem como lugar da expressão do sujeito leitor e possível zona de observação dos pesquisadores interessados nessa temática, pois nas cartas é possível encontrar as marcas de como o leitor se apropria da informação e os efeitos de sentidos da leitura sobre ele, ou seja, como leva a informação para sua vida quando lê. Conclusões: Ao interagir com o jornal, com os textos e os outros leitores, as cartas de leitores apresentam a apropriação da informação em curso, pois demonstram como o leitor se apodera das informações veiculadas, como constrói uma compreensão dos temas, deixando as marcas de quem é e de onde está situado social e historicamente.
\end{abstract}

Descritores: Mediação. Sujeito leitor. Análise do discurso. Jornal.

\footnotetext{
a Doutora em Ciência da Informação pelo Programa de Pós-Graduação da Universidade Estadual Paulista (PPGCI/UNESP). Docente do Programa de Pós-Graduação em Ciência da Informação (PPGCl) e do Departamento de Comunicação Social da Universidade Estadual Paulista (UNESP). E-mail: tamara.guaraldo@unesp.br
} 


\section{INTRODUÇÃO}

Para estudar a leitura e o leitor, tanto num contexto teórico quanto empírico, muitas abordagens são possíveis, tais como: análise de dados sobre alfabetização, interpelação direta do leitor em enquetes sociológicas, registros de locação e acesso a materiais de leitura, dados de venda e circulação, lista de Best Sellers, registro de leitores em diários, cartas e outros escritos, pesquisa em documentos como inventários, entrevistas pessoais, entre outros, para saber o que leem. Destacamos as cartas de leitores de jornais impressos em particular, como importante registro das práticas de leitura cotidiana, pois estão presentes em grande parte dos jornais impressos, saem diariamente na imprensa, estão no âmbito das relações leitor-jornal, e trazem questões sobre o uso do meio e a apropriação da informação por um sujeito leitor.

As cartas de leitores são textos publicados no interior de meios de informação impressos, e se localizam geralmente em uma seção fixa, de espaço determinado, destinado à publicação de correspondências do leitor. Essas cartas se referem a fatos do dia a dia, e apresentam a opinião do leitor sobre temas em foco e o seu entorno (mundo, país, localidade), publicam críticas ao jornal opinando sobre seu caráter e atuação, e também pedem providências, enfatizando o seu caráter mediador e levando a manifestações de pessoas ou entidades sobre questões diversas. Assim, demonstram a leitura e a atividade do leitor como uma mediação, por ser uma relação que envolve a ideia de constituir-se na relação com o outro, com o autor e outros leitores, com os temas sociais e consequentemente, com a sociedade e com os materiais de leitura.

Desse modo, esta pesquisa pretendeu, como objetivo geral, discutir 0 conceito de apropriação da informação apoiado no estudo bibliográfico e discussão crítica de trabalhos publicados sobre a seção cartas de leitores, com destaque à área de Comunicação e Informação. Foram pesquisados em bases de dados da internet: Scielo, Google acadêmico, e portal Base de Dados Referenciais de Artigos de Periódicos em Ciência da Informação (Brapci), trabalhos científicos em português com o descritor "cartas de leitores", 
publicados online após o ano 2000 e que continham dados pertinentes à pesquisa. No Scielo foram recuperados 20 registros e no Google acadêmico foram observados os trabalhos científicos listados até a página 10 de exibição, porém selecionados para análise apenas os que trouxeram discussões referentes à seção de cartas, suas características e problemáticas de publicação apresentando resultados de pesquisas aplicadas sobre a temática, e não se referindo apenas a análises de conteúdos específicos de cartas publicadas sem discutir a seção cartas de leitores. No portal Brapci foram recuperados e selecionados dois artigos. No geral, treze trabalhos atenderam este escopo.

Primeiramente apresentamos uma pesquisa bibliográfica sobre as cartas de leitores como gênero textual e sua contextualização histórica, utilizando-se autores como Andrade (2010), Marocco (2006), Chaparro (1992), Dines (2009), Assunção (2007) e Fontanini (2002). Em alternância com a apresentação histórica e contextual das cartas, discutimos e analisamos os trabalhos recuperados nas bases de dados consultadas, que são pertinentes à área Comunicação e Informação, e interpretados à luz do conceito de apropriação, ao viés analítico dos efeitos de sentido e elementos da análise do discurso. Foram analisados treze trabalhos: Ribeiro (2014), Espírito Santo e Dumont (2007, 2009, 2014), Guaraldo (2013), Zanotti (2013), Morigi, Rocha e Borges (2010), Morigi (2009), Adghirni e Baesse (2009), Baesse (2005), Silva $(2005,2008)$ e Braga (2004).

Neste cenário, entrelaçamos os dados obtidos nas pesquisas aos principais conceitos pertinentes ao entendimento da informação e suas práticas, em especial, ao conceito de apropriação da informação, em que as relações geradas pela mediação e uso levantam problemáticas sobre os efeitos de sentido gerados nos sujeitos em sua leitura cotidiana. Abordar as cartas de leitores, de modo particular, para estudar o conceito de apropriação da informação, situa a pesquisa no campo da mediação, pois as cartas de leitores possuem características que articulam o campo da produção e da recepção, demonstrando a leitura como mediação entre leitores e produtores em determinada situação histórica e social. 


\section{MEDIAÇÃO: APROPRIAÇÃO, RECEPÇÃO E EFEITOS DE SENTIDO.}

A mediação enfatiza o caráter social da informação, de que a mesma não existe fora da sociedade e da cultura, demonstrando as singularidades da questão informacional, das condições de produção e apropriação da informação. O conceito de mediação encontrou campo fértil em pesquisas que apontam que nada é imediato e, portanto, enfatizam a importância de intermediários, mediadores, nas mais diversas realidades sociais. É uma determinação em mostrar que nada pode ser dado como certo ou transparente nos fatos da cultura, de papéis sociais e formas simbólicas. Estudos de mediação recusam uma abordagem imediata dos fatos e põem em jogo os diferentes atores, procedimentos e dispositivos envolvidos numa dimensão simbólica e prática da cultura.

Davallon (2007) analisa a noção de mediação, refletindo sobre o estatuto científico do termo. Afirma que inicialmente, ao se falar em mediação, aparece à existência um terceiro elemento, aquele que torna possível a compreensão entre pessoas em conflito. No entanto, o autor questiona se a existência de um terceiro como um dado que constitui a mediação seria suficiente para defini-la.

Alguns usos da noção de mediação são apontados por Davallon (2007): o primeiro é o uso comum, que supõe um acordo entre partes que tem interesse distinto, e comporta a ideia de reconciliação. Contudo, ainda mais comum é a concepção da mediação como um tipo de prática ou ação, ou seja, a ideia de servir de intermediário para facilitar a comunicação (DAVALLON, 2007). Esse entendimento está presente na Ciência da Informação e na Comunicação quando apresentam procedimentos de mediação nas organizações e na atividade profissional de cada área (DAVALLON, 2007).

Além do mais, de acordo com Davallon (2007), a noção de mediação aparece quando há necessidade de descrever uma ação que implica uma transformação da situação ou do dispositivo comunicacional, não sendo uma simples interação entre elementos do processo, ou uma transferência de um elemento de um polo para outro. 
Emitirei assim a hipótese de que há recurso à mediação quando há falha ou inadaptação das concepções habituais da comunicação: a comunicação como transferência de informação e a comunicação como interacção entre dois sujeitos sociais. Com este recurso, a origem da acção desloca-se do actuante destinador ou dos inter-actuantes para um actuante terceiro: há comunicação pela operação do terceiro (DAVALLON, 2007, p. 10).

E o elemento terceiro está situado como um componente da linguagem, da intersubjetividade e do político; e neste processo, a comunicação se torna um produto da mediação e não o contrário, pois é a mediação que intervém para que a comunicação seja possível. Nos estudos de mediação da informação se destaca as ações de interferência em relação à informação, que podem ser diretas ou indiretas, conscientes ou inconscientes, implícitas ou explícitas, individuais ou coletivas, singulares ou plurais, que propiciem a apropriação da informação (ALMEIDA JUNIOR, 2009).

Uma preocupação da área de Ciência da Informação refere-se não somente à gestão e a organização da informação, mas à mediação, e em especial, a como as pessoas usam e se apropriam da informação. A informação não está no objeto e nem no sujeito, mas na mediação que se estabelece entre eles, sendo um processo histórico-social (ALMEIDA JUNIOR, 2009).

Este processo de orientação dos seres humanos no mundo não pode ser compreendido, de um lado, de um ponto de vista puramente subjetivista; de outro, de um ângulo objetivista mecanicista. Na verdade, esta orientação no mundo só pode ser realmente compreendida na unidade dialética entre subjetividade e objetividade. Assim entendida, a orientação no mundo põe a questão das finalidades da ação ao nível da percepção crítica da realidade (FREIRE, 2011, p. 67).

A apropriação como ação é um sair de si e buscar o outro, mas de modo discursivo, pois não se apropria da informação tal como ela é, e sim de um conceito elaborado pelo pensamento. Entendemos deste modo, que a apropriação da informação resulta da relação entre o sujeito e o objeto numa situação de mudança, numa reorganização e transformação do conhecimento, sendo um processo, portanto, de produção de sentidos. A ação de apropriar, como parte da recepção, é tornar algo próprio para um uso ou fim, um tomar para si, e que implica atividade, ainda que inconsciente. 
Almeida Junior (2007, p. 36) entende que a apropriação "[...] pressupõe uma alteração, uma transformação, uma modificação do conhecimento, sendo assim uma ação de produção e não meramente de consumo".

Nas análises de usos e mediações, termos recorrentes das pesquisas são as noções de recepção e de apropriação. A perspectiva de uso tem seu foco de interesse no ato do indivíduo que a partir de uma necessidade decide consumir o conteúdo de um meio de informação e comunicação: ler um jornal, uma revista, um livro, ir ao cinema, assistir TV, acessar internet, etc. Portanto, a recepção se inicia pelo fenômeno mais básico, a exposição do indivíduo, sem o qual nenhum outro efeito seria possível. A exposição aos meios é considerada parte da rotina diária, daí que, a recepção é uma prática social como outra qualquer, realizada de forma não estruturada, com baixo grau de envolvimento e sem motivação específica, tendo por cenário a vida cotidiana (RUÓTOLO, 1998).

Para Jeanneret (2009, p. 31) o termo recepção tem o interesse de destacar as práticas dos atores sociais: "[...] neste sentido possuem clara relevância para bibliotecas e web sites, bem como para programas de TV, os quais concentram a atenção de investigadores sociológicos". Contudo, para o autor, o termo recepção é bastante problemático, já que mistura uma dimensão logística, ou seja, o fato das produções dos meios serem recebidas de forma material; com uma dimensão simbólica, que oferece uma variedade de sinais para sua interpretação. Isto decorre do fato de que ao se deparar com um meio de informação e comunicação, seja um livro ou um filme, as pessoas se envolvem tanto num processo de mediação como numa participação com um dispositivo, o que acarreta envolvimento intelectual e físico, além de interpretativo. É que a vertente das mediações permite extrapolar a visão da comunicação como transmissão de informações e a recepção como o processo de atingir um destinatário. Porque o que acontece nesse processo é incerto e não previsto, e mesmo que cada mediação antecipe a etapa seguinte, o que predomina é a heterogeneidade e descontinuidade estrutural (JEANNERET, 2009).

As perspectivas de recepção entendem a exposição aos meios como algo 
rotineiro, automático, sendo que o interesse desses estudos estaria na construção subjetiva dos significados a partir dos conteúdos da comunicação, ou seja, da informação recebida (RUÓTOLO, 1998).

Thompson (2009) recorda que a recepção não pode ser confundida com uma simples aquisição, que nem sempre implica numa interpretação. É uma atividade de rotina, em cujo processo ocorre a apropriação, quando os indivíduos usam as formas simbólicas para suas próprias finalidades. É que o indivíduo deve prestar atenção (ler, olhar, escutar) e interpretar o conteúdo simbólico do meio que exige diferentes graus de atenção. E conforme conceitua o autor, ao interpretar as formas simbólicas, os indivíduos as incorporam na própria compreensão que têm de si mesmos, do mundo e dos outros, sendo esse "processo de conhecimento e de autoconhecimento denominado de apropriação" (THOMPSON, 2009, p. 45). Assim, apropriar-se é incorporar uma mensagem ao seu próprio cotidiano, às vezes com esforço, outras vezes nem tanto, num processo de adaptação do conteúdo as nossas próprias circunstâncias que podem ser bem distintas daquelas da enunciação/produção. Thompson (2009) também relaciona a apropriação à questão da transmissão de informação, porém, afirma que nem sempre essa é uma ação consciente de transformação da informação em conhecimento.

Para Almeida Junior (2007), é somente através da leitura que nos apropriamos da informação, pois se o documento permite a comunicação da informação, é pela leitura que sua linguagem será decifrada. Assim, a leitura é uma prática que só se dá no processo de mediação, que vai da comunicação via documento até a transformação do conhecimento de uma pessoa, pela apropriação da informação. Na leitura, deve-se considerar o conteúdo que o autor pretende veicular, a linguagem e característica do documento, a questão individual, porque é atribuição de sentidos que mobiliza o acervo de conhecimentos de cada um, mas também a prática coletiva, pois relaciona 0 leitor ao mundo e à história: "[...] a leitura exige trabalho, ela não ocorre sozinha, ela não se dá por si mesma" (ALMEIDA JUNIOR, 2007, p. 43).

Ainda quanto ao conceito de apropriação, Borges (2018) defendeu tese 
acerca do conceito compreendendo-o como um processo de materialização da informação dentro de uma perspectiva processual e semiótica, que se estabelece por interações sociais que não existem fora do ato da leitura. Nesta perspectiva, compreende-se que a apropriação da informação ocorre em um contínuo processo de construção, desconstrução e reconstrução, realizado na relação com o outro, por meio de diversas leituras de mundo realizadas por diferentes sujeitos que interagem dentro de um contexto histórico, social e cultural.

Outra concepção de recepção relacionada à leitura foi formulada no âmbito da Estética da Recepção, corrente apresentada por Zilberman (2009) como uma teoria que reflete sobre o leitor, a leitura, a experiência estética e as possibilidades de interpretação, e também como um movimento que surgiu no bojo das transformações vividas na década de 1960 no ambiente universitário ocidental. Ao iniciar o ano letivo de 1967, dois professores da Universidade de Constança, na Alemanha, Hans Robert Jauss e Wolfgang Iser, proferiram conferências em que promoviam uma nova história da literatura, da compreensão de seu significado na vida social e do papel do leitor. Aparecia como uma teoria em que a investigação mudava de foco: do texto para o leitor, principal elo do processo literário. Sua proposta era a de uma inversão metodológica: a de não analisar unicamente o autor e a produção do texto, mas o leitor e a recepção. O leitor é constituído num horizonte de expectativas, que é um misto do código vigente e das experiências sociais acumuladas; e de emancipação, como a finalidade e efeito que libera o leitor do usual e lhe dá nova visão da realidade.

Para a Estética da Recepção a vida histórica de uma obra não pode ser compreendida de forma alheia a participação de seu destinatário, pois a historicidade da literatura é feita de seus intercâmbios com o público. A obra se atualiza a cada leitura, prova de que está viva, mas de leituras que se modificam em cada época, demonstrando que a obra é vulnerável à história, pois não possui uma essência imutável, fora do tempo. "[...] Historicidade coincide com atualização, e esta aponta para o indivíduo capaz de efetivá-la: o leitor" 
(ZILBERMAN, 2009, p. 33).

Wolfgang Iser (1996) afirma que o que se apresenta como Estética da Recepção não tem uma unidade teórica como pode sugerir essa nomeação, pois detrás desse conceito, surgiram orientações distintas, apesar de recíprocas. De um lado, aparece a recepção, uma preocupação com a assimilação do texto, dependente de testemunhos, atitudes e reações, e que trabalha com método histórico e sociológico. De outro, o texto, como "prefiguração da recepção", um potencial de efeitos, que põe a assimilação em curso, operando com método teorético-textual.

Em Iser (1996) o texto possui uma estrutura de apelo em que a relação leitor e obra é uma modalidade de comunicação. Na Estética da Recepção, a literatura é uma forma de comunicação, o leitor é a entidade coletiva a quem o texto se dirige, a leitura é resultante dessa troca, e a experiência estética o efeito no leitor, o que situa essa corrente como um ramo da literatura, artes e comunicação, cuja teoria está preocupada com questões relativas à recepção (ZILBERMAN, 2009).

A Teoria da Estética do Efeito de Iser (1996) é uma perspectiva fundada na leitura porque é nesse processo que se realiza a interação fundamental entre a obra e seus leitores. A leitura dos textos é pressuposto indispensável, pois é um ato que antecede a interpretação e seus resultados. O Efeito Estético busca analisar a relação dialética entre texto, leitor e sua interação. É chamado de efeito estético porque, mesmo sendo motivado pelo texto, requer a imaginação e percepção do leitor. A leitura encontra-se no centro das preocupações de Iser (1996), pois é por meio dela que os processos provocados pelos textos podem ser observados.

$\mathrm{Na}$ leitura acontece uma elaboração do texto, que se realiza através de um certo uso das faculdades humanas. Desse modo, não podemos captar exclusivamente o efeito nem no texto, nem na conduta do leitor; o texto é um potencial de efeitos que se atualiza no processo da leitura (ISER, 1996, p. 15).

Os estudos da Estética da Recepção foram primordialmente estudos de teoria literária, da leitura literária e das formas de apropriação de seus leitores, contudo Stierle (2002, p. 122) também se dedicou à leitura pragmática, entendida 
"[...] como a forma de recepção elementar e comum a todos os textos". Stierle (2002) avalia que só é possível compreender as formas mais complexas de recepção quando primeiramente entendemos a recepção ingênua, que se automatiza nos contextos cotidianos de ação verbal na qual o sujeito da produção e o sujeito da recepção não estão isolados, mas social e culturalmente mediados, já que a leitura pragmática tem seu funcionamento assentado na mediação entre produtor e receptor, que intervêm como posições de papéis em um campo de ação: "[...] a comunicação pragmática funciona apenas porque o produtor consegue imaginar o papel de receptor e vice-versa" (STIERLE, 2002, p. 128).

Para Bortolin (2010, p. 87), o que a Estética da Recepção traz de mais inovador é "[...] a possibilidade de transformar o receptor no principal foco de investigação, deixando a obra literária de ser um objeto que existia por si só". E na Biblioteconomia é bem comum se dizer que não adianta os livros estarem organizados nas estantes se o leitor não tem acesso a eles, porém, é preciso ir além, pois não adianta o acesso "[...] se não há a recepção dos textos contidos neles por meio da mediação, seja ela informacional, tecnológica, cultural, literária; utilizando-se dos recursos de comunicação impresso, eletrônico ou oral" (BORTOLIN, 2010, p. 106).

Compartilhando o ponto de vista de que a leitura é produção de sentidos e consiste num trabalho do leitor, a Análise do Discurso (AD) surge no final da década de 1960 preocupada com a noção de leitura como uma opção a abordagem documental de textos, em que, a partir do estudo do discurso, promovia condições para uma determinada prática de leitura: uma nova maneira de "ler" (PÊCHEUX, 2010a).

Os efeitos de sentido aparecem relacionados tanto a uma leitura "literal" (a apreensão do documento) quanto à leitura interpretativa, que já é uma escritura, e constituem o que Pêcheux (2010b) chama de trabalho social da leitura, em que existem diferentes imagens de leitores e diferentes redes de interpretação. Assim, entende-se que o texto pode ser objeto de várias leituras, mas não pode ser qualquer uma. Orlandi (2008, p. 12) comenta que: "[...] ninguém lê num texto o que quer, do jeito que quer e para qualquer um. Tanto 
quanto a formulação (emissão), a leitura (compreensão) também é regulada". Isto posto, compreende-se que os sentidos não podem ir em qualquer direção e isso advém de sua relação com a exterioridade: das condições de produção, da memória, dos sujeitos na história, no discurso, na sociedade. As circunstâncias de um discurso ou as suas condições de produção compreendem os sujeitos e a situação, mas também a memória, que faz parte do discurso. Envolvem, em sentido estrito, as circunstâncias da enunciação, é o contexto imediato, e no sentido amplo, o contexto sócio histórico e ideológico (ORLANDI, 2009). O sujeito determina o que diz, mas também é determinado pela exterioridade em sua relação com o sentido.

$\mathrm{Na}$ perspectiva da $A D$, a leitura não pode ser vista como mera decodificação, apreensão de sentido que já é dado no texto e basta ser extraído. O texto é o lugar do jogo de sentidos, e é sempre heterogêneo quanto a sua forma simbólica, já que pode ser uma imagem, um som, uma grafia; também quanto à natureza da linguagem, pode ser um texto oral, escrito, cientifico, literário etc.; e quanto às posições do sujeito (MAINGUENEAU, 2002).

O sujeito, como ser de linguagem, está o tempo todo "cruzando informações", elaborando significados, no que resulta que não há signos seguros no processo de informação, pois a apropriação sempre envolve uma dimensão consciente e inconsciente, de desejos e conflitos. Daí que, não buscamos o sentido, mas os efeitos de sentido, pois no processo informacional não trabalhamos apenas com o emissor e o receptor, mas com vozes, ecos de outros discursos. Quantas vezes ouvimos uma canção no rádio e horas depois a cantamos sem necessidade alguma? E a apropriação da informação, que é um tornar próprio, se faz, preferencialmente através da leitura, de forma ampla, que não está limitada a palavra escrita, mas uma leitura que envolve interpretação dos mais variados textos.

Resta ainda dizer que falar em apropriação da informação sem falar da leitura é uma tarefa incompleta. Afirmo com muita segurança e convicção que apenas a prática das múltiplas leituras, de preferência realizada em sua verticalidade, possibilita ao indivíduo a apropriação da informação (BORTOLIN, 2010, p. 123). 
Compreendemos deste modo, a apropriação da informação como um sair de si e buscar o outro, mas de modo discursivo, pois não se apropria do objeto tal como é, e sim de um conceito elaborado pelo pensamento. O conhecer tem origem no agir. Conhecer é se apropriar, tomar posse, agir e modificar uma circunstância. A apropriação seria parte de um processo de formação pessoal e de autocompreensão nem sempre explícito e reconhecido como tais, pois ao apoderar-se dessas mensagens rotineiras, o sujeito age e marca sua posição no discurso, constrói uma compreensão de si e deixa marcas ideológicas e de onde está situado social e historicamente.

\section{AS CARTAS DE LEITORES DE JORNAIS IMPRESSOS COMO ESPAÇOS PRIVILEGIADOS DE APROPRIAÇÃO DA INFORMAÇÃO}

Refletindo sobre a presença histórica do sujeito leitor de jornal, Marocco (2006) aborda autores como o sociólogo Sunmer (1840-1910), que destacou a figura do leitor como "povo", no Século XIX, e que nesta época a imprensa se dedicava ao "homem comum", excluindo questões de filosofia e política, por julgar inadequadas para o debate público. Ao discutir a imprensa popular de massa do século XIX, Martín-Barbero (2008) afirma que por trás da noção de sensacionalismo há um rompimento da objetividade e um encontro ao ponto de vista subjetivo dos leitores. Nesta linha de raciocínio, Marocco (2006) afirma que a questão a ser pensada é em torno da existência do leitor no interior dos jornais, da sua presença no discurso do jornal, o que identifica a trajetória das cartas de leitores como espaço presente na imprensa, que ganhou impulso significativo após a massificação do jornalismo, que decorreu a partir de meados do século XIX:

Neste contexto, o The New York Times foi o primeiro jornal a publicar uma carta de um leitor num espaço inteiramente dedicado à opinião dos cidadãos, a 18 de Setembro de 1851, apenas cinco dias após o seu lançamento. No caso português, seria o Expresso o primeiro a optar por esta mesma via, a 18 de Dezembro de 1972, seguido dos exemplos do jornal A Capital, já em finais de 1973, com a rubrica Opinião Pública (RIBEIRO, 2014). 
Até o final do Século XIX, o jornal buscava o apoio de uma série de fontes de informação para narrar o cotidiano da cidade: cartas não identificadas, relatos de vizinhos, parentes. Não havia ainda o distanciamento da imprensa com o leitor, que participava do diálogo direto com o jornal. Após o início do Século XX, "[...] o leitor é desterrado da notícia para um outro espaço, a seção de cartas, onde poderá ser flagrado em uma miríade de situações" (MAROCCO, 2006, p. $5)$.

Andrade (2010) realizou pesquisa sobre a carta do leitor como um gênero discursivo no qual se ilustra as interações entre o escrevente e seu interlocutor, por meio de marcas linguísticas nas cartas publicadas em jornais paulistas do século XIX: Farol Paulistano, Diário de São Paulo, A Província de São Paulo, Correio Paulistano. Nesta época, ainda não se configurava de modo explícito a mediação do jornal sobre o conteúdo da carta, conforme descreve a pesquisadora:

Sabemos que nem toda carta do leitor é publicada, pois há sempre uma triagem para a seleção das cartas a ser, efetivamente, publicadas e entre aquelas que são selecionadas para publicação pode haver ainda uma edição [...] Entretanto, nos jornais do final do século XIX não é bem isso o que se vê. $\mathrm{Na}$ verdade, nos jornais selecionados as cartas são colocadas integralmente e versam sobre os mais variados e distintos assuntos vividos pela sociedade da época e noticiados nos jornais ou sobre temas pessoais: pedidos, reclamações, comentários, busca de contato com parentes ou amigos, entre outros (ANDRADE, 2010).

A pesquisa aponta ainda que a carta do leitor era muito produtiva e, que esse gênero "[...] parece ter se transformado no artigo jornalístico muitas vezes rotulado de opinião" (PESSOA, 2002, p. 201-202 apud ANDRADE, 2010). A autora conclui que a seção de cartas nesta época servia como uma espécie de consultório de reclamações, pedidos ou mesmo para estabelecimento de contato com parentes ou amigos, comentário sobre matéria publicada, comentário ou crítica a políticos, sobre as escolas públicas, as condições das estradas, iluminação pública, limpeza urbana; biografia; confissão; e que por meio das cartas, buscavam alcançar propósitos específicos e variados (ANDRADE, 2010).

No Brasil foram os jornais O Estado de S. Paulo e a Folha de S. Paulo, 
(na época Folha da Manhã) que publicaram as primeiras cartas de leitores, no formato que permanece atualmente - como uma seção específica e mediada pela publicação-, na década de 1950. A mediação exercida pela Folha era explícita e as cartas eram "cortadas, enxertadas de discursos do jornalista, destacadas por recursos gráficos como aspas, negritos, reticências, antes de transcrever o texto do leitor" (CHAPARRO, 1992, p. 73). No O Estado de S. Paulo, as cartas eram publicadas sem a mediação explícita, com o texto integral do leitor, formatação que se mantém até hoje na maioria dos veículos da imprensa (CHAPARRO, 1992).

As cartas de leitores, um gênero textual dos meios de informação impressos, também são chamadas de cartas ao editor, cartas à redação, correio do leitor ou painel do leitor, e relaciona o leitor e os demais leitores à publicação. As cartas pertencem ao gênero opinativo, e estão no âmbito das relações sujeito leitor-jornal como importantes registros das práticas de informação e leitura, em que o leitor opina e colabora com o periódico, e "[...] é a manifestação opinativa, reivindicatória, cultural ou emocional do leitor" (CHAPARRO, 1992, p. 63), resultando, enfim, no uso do meio e apropriação da informação pelo sujeito leitor.

Ao estudarmos as práticas de informação e leitura, devemos levar em conta a comunidade e um campo específico de conhecimento ou de ação na qual o leitor ou usuário está implícita ou explicitamente inserido (CAPURRO, 2003). Dines (2009) corrobora essa opinião, pois não concebe o leitor como um fato isolado ou singular, e sim como fração de um universo:

O que acontece com um leitor está acontecendo simultaneamente com o conjunto que ele representa. É por isso que a seção "Cartas de leitores" tem tamanha importância num jornal, pois não atende apenas àqueles que se armaram de paciência e coragem para escrever ao periódico, mas a todos aqueles que não tiveram a mesma disposição, mas assim pensam (DINES, 2009, p. 74).

As cartas de leitores se apresentam como um importante material que registra os efeitos de sentidos da leitura por um sujeito leitor, pois ao saírem diariamente na imprensa, se referem a fatos do dia a dia, apresentam o texto do leitor como um potencial de efeitos de sentidos que se atualizam no processo da leitura, como sugere Iser (1996), pois elas trazem a opinião do leitor sobre os 
temas em foco e o seu entorno (mundo, país, localidade); apresentam críticas ao jornal opinando sobre seu caráter e atuação; e também pedem providências, levando a manifestações de pessoas ou entidades sobre irregularidades ou questões diversas.

Quanto a pesquisas no âmbito acadêmico sobre o leitor e a leitura de jornal (com exceção da leitura de jornal no campo escolar) no Brasil, existem poucas investigações, pois "[...] as teorias desenvolvidas no campo da recepção, nos últimos 80 anos não trataram do leitor de jornal em particular, sempre o consideram como um anônimo dentro de uma massa compacta denominada audiência" (BAESSE, 2005, p. 75).

Baesse (2005) afirma que os estudos sobre o leitor são geralmente patrocinados pelos próprios meios, e não tem por objetivo a compreensão do leitor de jornal num âmbito mais amplo.

Em estudos de linguagem, Assunção (2007) estuda as cartas de leitores a partir do conceito de gênero e de reescrita, caracterizando-as por possuírem uma "proposta comunicativa": a de apresentar aos meios de informação o parecer do leitor referente aos temas publicados ou ao próprio meio. A noção de comunidade discursiva é utilizada para ressaltar que os leitores compartilham certo grau de conteúdo e estratégias discursivas através de um meio que possibilita a comunicação entre os pares (ASSUNÇÃO, 2007).

Para Assunção (2007) as cartas de leitores são plenamente intertextuais, pois são escritas, na maior parte das vezes, em referência a textos já publicados em edições passadas de um meio de informação impresso. Fazem, portanto, referência às questões tratadas pelo meio para a qual foram escritas e aos outros leitores, remetendo tanto ao próprio texto quanto ao contexto. Ainda, as cartas trazem como condições de publicação a identificação do remetente, aproximando-se das cartas pessoais, contudo, dessas se distinguem, pois não são feitas para guardar ou arquivar, mas para serem publicadas. Quanto à estrutura das cartas, essas são textos pequenos, em geral de um parágrafo, em que se dispensam as aberturas e fechamentos tradicionais das cartas, pois vão direto ao assunto, e são organizadas sob uma rubrica (tema) definida pelo editor, 
demonstrando o modo como esse lê a carta e define para elas uma temática comum, e também alertando ao leitor quanto ao espaço e a clareza do material enviado para ser publicado (ASSUNÇÃO, 2007). Existe a preocupação com o que é dito e como isto é dito, mostrando o modo como os leitores leem:

A importância das cartas de leitores consiste no fato de elas acentuarem o caráter dialógico dos meios de informação, pois ao publicarem as cartas dos leitores, a princípio, independente do conteúdo veiculado, o jornal não só dá voz aos seus leitores, permitindo que eles possam interagir não só com o jornal, mas também com os outros leitores. Além disso, as cartas de leitores funcionam como um termômetro, pois além de demarcar os interesses dos leitores, demonstra o seu grau de receptividade da matéria e do trabalho desenvolvido pelo periódico (ASSUNÇÃO, 2007, p. 673).

O texto disponibilizado neste espaço é assentado na ausência de contato imediato entre leitor e emissor (publicação), uma comunicação mediada. A carta, para ser disponibilizada, passa pela figura do editor, que a seleciona e dissemina no espaço do leitor, num processo de mediação implícita. Do ponto de vista jornalístico, o editor é o mediador desse espaço, pois seria o intermediário entre o cidadão e as autoridades, entre o leitor e o jornal (CHAPARRO, 1992).

A seleção e editoração das cartas, entretanto, permanece sob o controle de um editor. Embora um certo grau de "limpeza" editorial seja efetuado, para garantir que não sejam difamatórias ou grosseiramente ofensivas, as cartas ao editor podem nos trazer insights sobre dimensões socioculturais de uma comunidade, conforme evidenciadas pelos leitores/escritores (SOTILLO; NASTASI, 1999 apud FONTANINI, 2002, p. 227).

No entanto, Chaparro (1992, p. 63) alerta que a carta, dentro de um processo industrial de comunicação, "[...] é uma concessão ao leitor, administrada em proveito do jornal, em cujas mensagens o leitor só acidentalmente interfere".

Dentre as pesquisas que selecionamos para análise ${ }^{1}$, Braga (2004) situa as cartas de leitores como um dos dispositivos de expressão e de circulação da crítica social da mídia, "[...] sem os quais a manifestação social se restringe a espaços pessoais ou micro-grupais, sem impacto relevante sobre os processos

\footnotetext{
${ }^{1}$ A partir de agora apresentamos as pesquisas selecionadas para análise em ordem crescente, das mais antigas às mais recentes.
} 
mediáticos (de produção e de uso geral)". O autor, assim como Chaparro (1992), também minimiza a relevância do espaço para a constituição de um debate público, ainda que reconheça seu papel de espaço privilegiado para o debate:

Efetivamente, é o espaço em que o leitor e o jornalista podem cotejar perspectivas sobre os acontecimentos sociais; em que os leitores falam com o jornal, no jornal e eventualmente sobre 0 jornal. Aquelas esperanças de um debate relevante e significativo não parecem, entretanto, ter se confirmado (BRAGA, 2004, p. 8).

Nesta perspectiva interessa menos pesquisar o retorno imediato e pontual relacionado à interatividade das cartas e sua efetividade ou relevância ao processo de comunicação, e mais os usos feitos da interatividade, assim como as potencialidades e desafios aos usuários (à sociedade, portanto) como um instrumental crítico e interpretativo que possa ampliar sua competência de "leitura". Em levantamento feito pelo autor e realizado em 2001, nos jornais Folha de São Paulo, Jornal do Brasil e Correio Braziliense, em um mês de colunas de leitores acompanhadas dia a dia, menos de $20 \%$ das cartas faziam alguma referência expressa a uma matéria publicada no jornal, a maioria, $80 \%$ se referiam a acontecimentos e situações da sociedade (BRAGA, 2004).

Baesse (2005) estudou as cartas de leitores como elemento de crítica da sociedade e buscou compreender como o leitor se manifesta, coletando cartas de jornais diários e analisando, com o auxílio da Análise de Conteúdo, as cartas de leitores em três categorias: intermediação, quando os leitores, através das cartas buscavam soluções para problemas cotidianos; na categoria mediação foram enquadradas as cartas de queixas e contrariedade, mas que não buscavam uma resposta em particular; e a terceira, chamada de crítica da mídia, em que os leitores discutiam o próprio papel do meio de informação na sociedade e faziam críticas a ele, com debates sobre a função da imprensa e a liberdade de expressão (BAESSE, 2005). A categoria mediação foi a que mais contabilizou no total de cartas dos jornais analisados e, segundo Baesse (2005, p. 80), isso demonstra que o leitor - chamado pela autora de leitor manifesto - "[...] quer um espaço para falar o que pensa". Quanto à seção de cartas de leitores, para Baesse (2005) os jornais conseguem estabelecer interatividade entre os 
leitores/escritores, ainda que num diálogo atrasado no tempo, sendo um espaço de crítica da mídia dentro do próprio jornal, mas reconhece que essa poderia ser mais bem trabalhada pelos jornais.

Silva (2005) comenta em seu estudo que as cartas de leitores não têm sido objeto de investigação em Portugal e nem mesmo em outros países. Para a autora, que realizou pesquisa junto ao jornal português Público, num período de dois meses, "[...] há poucos estudos sobre esta matéria e grande parte dos que existem estão inseridos em investigações de âmbito mais vasto" (SILVA, 2005 , p. 12)2. A pesquisadora também observou que os leitores/escritores que têm mais recursos persuasivos e se expressam melhor têm maiores condições de ver suas cartas publicadas (SILVA, 2005, 2008).

A opinião de que este espaço é pouco valorizado pelos veículos também pode ser confirmada por outra pesquisa selecionada que analisou e levantou 0 espaço em que dez dos principais jornais brasileiros dedicam à seção de cartas. As autoras Adghirni e Baesse (2009) investigaram as cartas de leitores dos seguintes jornais do centro-sul: Folha de S. Paulo, Estado de São Paulo, Jornal do Brasil, O Globo, Correio Brasiliense e Zero Hora; e do norte-nordeste: A Crítica, O Liberal, Diário de Pernambuco e A Tarde. A pesquisa concluiu que da média de 50 a 70 páginas de um jornal diário, o espaço do leitor não chega a ocupar uma página nos grandes jornais. A conclusão a que se chega é a de que o "[...] espaço do leitor não tem crescido dentro dos jornais impressos, e são poucos aqueles que realmente tratam a coluna com o devido respeito" (ADGHIRNI; BAESSE, 2009, p. 12).

Num enfoque informacional, Espírito Santo e Dumont (2007 e 2009), estudaram as cartas de leitores e consideraram os meios como mediadores de informações, buscando entender a mulher atual como leitora de jornais de referência, pois elas são parte considerável do leitorado de jornais:

Os jornais se configuram, então, como fontes de informação muito valorizadas pelo feminino. E elas lêem de tudo. É essencial para aquela que espera encontrar na leitura momentos

\footnotetext{
${ }^{2}$ As pesquisas de Silva $(2005 ; 2008)$ e de Ribeiro (2014) são no âmbito das rotinas produtivas na seção de cartas, investigando critérios de seleção e edição junto à redação dos jornais.
} 
de lazer e vital para a que busca informação, que tem necessidade de acessar 0 saber não acadêmico, 0 conhecimento elaborado a partir dos acontecimentos cotidianos, para assim participar da vida pública. A mulher parece ser uma grande consumidora de informação. Há um século liam pouco, sobre poucos temas e reservadamente. Hoje lêem de tudo e contam sobre o que leram aos quatro cantos do mundo. Não clamam por uma informação direcionada especialmente a elas, mas que as considerem e as reconheçam como sujeitos de ação. Elas são noticiáveis, tanto quanto os homens. Estão longe de ser ao menos a metade, nas altas instâncias do poder, mas estão atentas ao que se passa ao seu redor e no mundo (ESPÍRITO SANTO; DUMONT, 2007, p. 10).

Em outra pesquisa específica sobre as leitoras do Jornal Estado de Minas (MG), de caráter quantitativo e qualitativo, as autoras primeiramente levantaram o total de correspondências enviadas a seções de cartas de leitores de sete jornais brasileiros que estavam assinadas por mulheres, num período de 30 dias. Das 1848 cartas publicadas, 1493 eram de homens e 345 de mulheres (ESPÍRITO SANTO; DUMONT, 2009). E mais especificamente, em relação às leitoras do Jornal Estado de Minas, foi aplicada entrevista por telefone a 172 leitoras; além da análise do discurso de capas do jornal e de matérias internas que tinham a mulher como personagem. O estudo revela que a mulher corresponde à quase metade do público leitor dos grandes jornais brasileiros e usa a informação desse meio para formar sua opinião e interagir socialmente, mas ainda participa desse espaço de forma desigual (ESPÍRITO SANTO; DUMONT, 2009).

Outro estudo do leitor contemporâneo no processo informacional realizado por Morigi, Rocha e Borges (2010) demonstra, através de análise de cartas, como o jornal impresso exerce a mediação, ao circular as representações expressas nos conteúdos informacionais dos leitores. De um total de 115 cartas de leitores participantes do concurso "A Minha Capital”, promovido pelo jornal Zero Hora (RS) no ano de 2007, foram selecionadas 10 dentre aquelas publicadas pelo jornal durante o mês de março. Os dez narradores selecionados tinham idades entre os 29 e os 64 anos e foram divididos equitativamente entre homens e mulheres, sendo todos de escolaridade de nível superior e da classe média e alta; oito eram moradores de Porto Alegre e os outros dois passaram 
parte de suas vidas ali.

As narrativas refletem o trabalho de memória dos leitores, através das suas lembranças sobre a cidade. Neste sentido, recuperar a memória dos cidadãos sobre a cidade de Porto Alegre significa considerar que cada leitor não apenas participa individualmente como cidadão, mas compartilha com os demais das representações e das práticas que compõem o imaginário e a identidade cultural dos porto-alegrenses (MORIGl; ROCHA; BORGES, 2010, p. 103).

A pesquisa evidencia que o jornal impresso reforça os laços dos leitores com a cidade e sua identidade cultural ao veicular os conteúdos informativos de suas narrativas. E ainda, Morigi (2009) afirma que as cartas trazem representações sobre a cidade, identificam informações sobre lugares a partir de lembranças e ajudam a construir um imaginário local, mediando à memória coletiva dos leitores.

Guaraldo (2013) abordou as cartas de leitores como uma prática de informação e leitura cotidiana, uma mediação em que efeitos de sentido são produzidos a partir da apropriação da informação. Foram selecionadas trinta cartas de leitores tendo como tema a mudança de layout e editorias de um jornal popular, o Bom Dia Bauru, em setembro de 2010 e os impactos na prática de leitura, com uso da metodologia da análise do discurso. As cartas de leitores analisadas demonstraram que os leitores, em sua maioria homens, são ativos na maneira em que aceitam, negam ou reproduzem o discurso do jornal no processo de recepção, com destaque as apropriações e resistências de leitores e leitoras na aceitação do novo Bom Dia, salientando as diferentes posições que o leitor pode ocupar, não sendo sempre o mesmo.

Zanotti (2013) destacou em sua pesquisa o impulso dado pelo correio eletrônico à seção de cartas, com o aumento da intensidade do fluxo informacional levando jornais e revistas impressos a ampliarem este espaço, assim como os portais noticiosos que incorporaram fóruns de discussão em suas páginas. $O$ autor estudou meios de informação pertencentes a um mesmo grupo editorial da cidade de Campinas, a Rede Anhanguera de Comunicação (RAC), composta por: um jornal diário "Correio Popular", o portal "Cosmo Online" e a revista "Metrópole". Uma das conclusões da pesquisa é a de que as cartas 
enviadas aos veículos analisados foram em sua maioria escritas por leitores de classe social mais elevada, "[...] o que implica no fato de que a parcela excluída do desenvolvimento também se faz excluída dos meios de comunicação enquanto membros proativos" (ZANOTTI, 2013, p. 75).

Em pesquisa mais recente das autoras Espírito Santo e Dumont (2014), foram coletadas cartas enviadas em caráter espontâneo, por e-mail, ao jornal Estado de Minas, no período de 30 dias, e realizou-se análise do discurso de 60 cartas, separando-as por temáticas. As cartas foram abordadas como instrumentos de transmissão de informação sobre a vida em sociedade. As principais questões levantadas apontam que os leitores utilizam o espaço muito mais para ter sua opinião publicada sobre os fatos do que para criticar 0 tratamento que o jornal dá aos temas político/social, de reivindicação e/ou de desabafo e que os homens escrevem mais para os jornais; assinaram $79 \%$ das cartas enviadas e dominaram o espaço da coluna com $78 \%$ das cartas publicadas. As mulheres são $47 \%$ do público leitor do jornal. Uma das explicações apresentadas é a de que a sociedade valoriza mais a escrita doméstica para a mulher, do que a escrita pública: "[...] as mulheres não se interessam em ter os refletores voltados para si, no que diz respeito ao espaço do leitor, tanto quanto os homens" (ESPÍRITO SANTO; DUMONT, 2014).

Ribeiro (2014) estudou as cartas de leitores na imprensa portuguesa, também no Jornal de Notícias, e observou que as cartas continuam a ter um papel reivindicativo, pois nelas se destacam o tom crítico e negativo, onde queixas, reclamações e desabafos são predominantes para expressar 0 cotidiano dos leitores, sendo os elogios e as sugestões bastante residuais. E que este espaço poderia ser um encontro de jornalistas, mídia e leitores referente ao debate público: "O desafio, a nosso ver, poderá consistir em articular as infinitas possibilidades de participação online com as em papel, criando, por exemplo, locais onde os melhores comentários às notícias online ocupem, de algum modo, um espaço importante no papel" (RIBEIRO, 2014, p. 47). Ribeiro (2014) alerta para a necessidade de se pensar em novas formas de atribuir um papel mais credível e importante ao leitor, o que se pode relacionar à mediação realizada 
pelas publicações, pois as cartas, ainda que editadas, são um dos formatos observáveis de uma tentativa de expressão, que pode influenciar e repercutir sobre a produção da informação a partir das apropriações e manifestações do público leitor.

Identificam-se nas pesquisas estudadas, as cartas de leitores como espaços de mediação, em diferentes graus, que vão desde a articulação entre o campo da produção e da recepção, demonstrando a leitura como mediação entre leitores e produtores em determinada situação histórica e social; assim como o simbolismo da própria carta enviada à redação também vista como a mediação de uma leitura efetuada; a interferência dos agentes, com a figura do mediador, no caso o jornalista; e também o simbolismo do próprio dispositivo como uma mediação com suas regras e formatos; sendo o próprio espaço "cartas de leitores" um discurso mediado, no qual a comunicação não acontece de maneira direta entre os interlocutores, mas também não se configura num espaço apenas voltado à transmissão de informação. Se o recurso à mediação aparece quando há falha nos conceitos básicos de comunicação como interação entre dois sujeitos sociais ou transmissão de informação (DAVALLON, 2007), é este o caso das cartas de leitores. Este espaço não comporta a ideia de comunicação como diálogo, pois a comunicação do leitor com o jornal só se torna possível pela ação de um terceiro, ou seja, a carta enviada à redação. Também não há a concepção de comunicação como transmissão de informação, pois a leitura produz efeitos sobre o leitor que não são de todo previsíveis, e esse pode se manifestar ou não a respeito de sua leitura, configurando-se assim, num espaço de mediação segundo Davallon (2007). A carta enviada ao jornal irá sofrer mudanças em sua forma e conteúdo, não há neutralidade da informação na relação entre emissor e receptor, o que também a situa no campo da mediação da informação de acordo com Almeida Junior (2009), ao enfatizar a noção de interferência. A ação do jornal ao publicar a carta, gera efeitos sobre o leitor que tem a sua prática de leitura considerada pelo meio. Assim, a mediação se estabelece pelo amplo confronto desses sujeitos no processo de recepção, que envolve o meio de informação, os leitores e sua cultura, e dessa negociação se constrói o 
significado das mensagens (RUÓTOLO, 1998).

As cartas de leitores, como registro de uma prática de leitura, têm um caráter público e mediador, pois apesar de produzidas em um espaço institucional com certas regras, são feitas para serem divulgadas, e carregam ao mesmo tempo, as marcas do leitor que escreve e as do jornal que as seleciona e publica. Estão presentes nas cartas as condições de produção da própria publicação, que delimita o espaço e a ordem do discurso: é preciso falar de modo claro, pois sem as normas não é possível comunicar e elas variam segundo a instituição. A instituição não pode ser separada dos discursos que emite (MAINGUENEAU, 2011).

Nas pesquisas analisadas, é evidente também o destaque dado ao papel do sujeito em referência a um grupo maior de leitores, corroborando o que Zilberman (2009) entende por experiência estética e as possibilidades de interpretação, ao situar o leitor num horizonte de expectativas referente a uma época e aos demais leitores, ao que é dito, aos temas atuais, e as preocupações e acontecimentos sociais, num misto do código vigente e das experiências sociais acumuladas; mas também de emancipação, quando esse sujeito leitor aborda assuntos críticos e importantes para a comunidade de leitores e oferece ao grupo uma nova visão da realidade que propiciará novos efeitos de sentido.

Por fim, sendo as cartas intertextuais por excelência (ASSUNÇÃO, 2007) não se pode deixar de notar a comunicação que se estabelece entre os próprios leitores sobre os temas abordados pelos jornais, como pontuaram Espírito Santo e Dumont (2014, p. 187):

Percebe-se que 24 cartas, entre as 60 analisadas, trouxeram referências a outras cartas publicadas pela coluna, sendo que 18 foram publicadas. Dessa forma, a coluna quer passar a impressão de que dá ao/as leitores/as espaço para que discutam entre si pontos de vista sobre temas abordados pelo jornal, assim como sobre temas introduzidos pelos/as próprios/as leitores/as.

Sendo, portanto, as cartas um espaço de manifestação de opinião, interação e intertextualidade, podem ser compreendidas numa perspectiva discursiva como a presença do papel do Outro no discurso via efeitos de sentido, pois aparece não só a opinião do leitor, mas outras vozes, ecos de outros discursos e leituras. 
Na linha da Análise do Discurso de perspectiva materialista, a sociedade está sujeita à dominação de classe em que os meios de informação e comunicação estão sob o domínio de certas classes, e ainda que os leitores possam refutar e negociar com os conteúdos vindos dos meios, eles não têm um poder efetivo frente a eles. Notamos na análise dos trabalhos referentes às cartas de leitores analisados, que apesar dos leitores terem as cartas para se posicionar e discutir o que está em jogo na leitura do periódico, num espaço que até pode estar bem destacado, essa posição nem sempre é considerada para desencadear uma ação por parte do jornal. O espaço das cartas de leitores, apesar de ser considerado importante (e deveria ser) por alguns estudiosos (DINES, 2009), ainda ocupa um espaço secundário no jornal (ZANOTTI, 2013; ADGHIRNI; BAESSE, 2009), ou conforme Chaparro (1992), ainda é uma concessão que o jornal faz ao leitor, já que o poder de decisão, a palavra final, lembramos, está nas mãos do jornal. Esta condição foi destacada na pesquisa de Zanotti (2013, p.75) que apontou:

[...] as cartas dos leitores proativos das publicações analisadas referem-se basicamente aos temas propostos pelas publicações nas coberturas que realizam. Primeiramente, por que a própria política editorial dos periódicos induz seu leitor, através do conjunto de cartas publicadas, a referir-se exclusivamente aos conteúdos noticiados; e em segundo lugar por que não há, nos espaços destinados aos leitores, principalmente em se tratando do meio virtual, a possibilidade de abrir novas temáticas. Assim sendo, a pró-atividade do leitor em questão é relativizada em função de projetos editoriais que, no jornalismo contemporâneo, desestimulam a introdução de novas temáticas no universo de coberturas noticiosas.

Portanto, "É preciso assinalar que a interação jornal/leitores é desigual" afirma Braga (2004), mas que isto não pode ser interpretado como incompetência ou má-fé, e sim questões inerentes ao próprio processo de recepção/seleção/publicação das cartas de leitores, num espaço limitado, de controle e de edição. Contudo, também existe um poder simbólico, pois, este também é o campo da leitura interpretativa (PÊCHEUX, 2010b) em que diferentes leitores ocupam posições diversas num jogo de efeitos de sentido de um sobre o outro. Assim, os leitores que escrevem ao jornal preocupam-se em marcar sua posição no texto, demonstrando a sua apropriação da informação 
veiculada e também dos temas cotidianos que lhes afetam.

À vista disso, no estudo das cartas de leitores nota-se que despontam realidades diferenciadas, em que questões sociais - a mediação dos jornalistas como ação de interferência (conforme: BRAGA, 2004; SILVA, 2005 e RIBEIRO, 2014), e manifestações de leitores sobre o cotidiano da cidade (MORIGI, ROCHA, BORGES, 2010); de leitura - a receptividade, os diferentes efeitos de sentido que provocam no sujeito leitor (BAESSE, 2005; GUARALDO, 2013); de gênero - a baixa representatividade feminina (ESPÍRITO SANTO; DUMONT, 2009; GUARALDO, 2013; ZANOTTI, 2013), ideológicas - o poder do leitor e o poder do jornal, por exemplo, surgem junto a outras como questões de classe, de acesso e uso dos dispositivos, espaços e meios de leitura. É evidente também que a participação dos leitores no espaço das cartas foi impulsionada pela internet e facilidades de uso do correio eletrônico, sendo que grande parte delas é enviada por esse meio (GUARALDO, 2013; e ZANOTTI, 2013).

Quanto à apropriação da informação, as cartas de leitores, de acordo com a literatura selecionada para análise, podem ser compreendidas como espaços privilegiados dentro dos meios de informação impressos para os estudos de apropriação da informação, já que se constituem como lugar da manifestação do sujeito leitor e possível zona de observação dos pesquisadores interessados nessa temática, pois nas cartas é possível encontrar as marcas de como o leitor se apropria da informação e os efeitos de sentidos da leitura sobre ele, ou seja, como leva a informação para sua vida quando lê.

Defendemos as cartas de leitores como objeto de estudo privilegiado para as pesquisas sobre mediação, apropriação e leitura, já que se constituem como um espaço dentro dos meios impressos em que se pode observar a apropriação da informação por um sujeito leitor, sendo que essa ocorre em diferentes graus, porque é uma ação que demonstra um "[...] impulso interativo, de dar retorno e de se expressar, que inclui também um objetivo de "agir sobre" (BRAGA, 2004, p.12), que pode ser consciente ou inconsciente, pode demandar esforço interpretativo ou não, e que significa apoderar-se de uma mensagem e incorporála à própria vida. 


\section{CONSIDERAÇÕES FINAIS}

A informação, para ser apropriada, depende da leitura, dos leitores e dos efeitos de sentido intermediando a construção do conhecimento. Ao refletir sobre a apropriação da informação e os efeitos de sentido produzidos por um sujeito leitor, precisamos levar em conta esse sujeito do discurso afetado pela ideologia e inserido na história e na sociedade. E assim a tensão se estabelece: de um lado, o papel ativo do sujeito na leitura e na produção de sentidos, de outro, esse mesmo sujeito determinado pelas circunstâncias de sua prática de leitura. A AD vai além do nível linguístico para compreender a ideologia que permeia os discursos, e assim incorpora também o universo simbólico que justifica as ações dos sujeitos informacionais.

Com o aumento do fluxo informacional trazido pelas possibilidades de interação via tecnologias na sociedade da informação, se amplia também as possibilidades de estudo das manifestações dos leitores tanto em veículos impressos quanto em portais noticiosos, trazendo novos elementos para compreender os discursos e as demandas destes sujeitos que levantam temáticas, agitam a opinião pública e demostram sua apropriação do que é publicado nos veículos pelos quais se informam, podendo contribuir para entender e aperfeiçoar o papel social que a informação e a leitura desempenham na vida cotidiana.

Espera-se que o estudo das cartas de leitores por meio da AD, como uma fundamentação capaz de revelar aspectos do discurso e da leitura relacionados ao contexto social, possa contribuir para a compreensão da apropriação da informação pelo sujeito leitor e que se apresente como mais um caminho para apoiar os estudos de mediação e apropriação da informação. Já a experiência estética se faz presente quando as cartas de leitores referem-se aos acontecimentos cotidianos e aos demais leitores, e assim também promovem a emancipação quando produzem efeitos de sentido no leitor e este, ao se apropriar da informação e opinar sobre temas sociais e críticos, pode ver a realidade sob outra perspectiva. 
Porque da prática de leitura, efeitos são produzidos, já que o sujeito leitor exerce papel ativo em sua atividade interpretativa, sendo a leitura um trabalho de interpretação e uma prática que se constitui em maneiras de ler que são ao mesmo tempo individuais - como a parte subjetiva da relação que o leitor estabelece com o texto - mas também coletivas, pois circunscritas a um universo social, histórico e ideológico.

Ao interagir com o jornal, com os textos e os outros leitores, as cartas de leitores se apresentam como um espaço privilegiado de apropriação da informação, pois demonstram como o leitor se apodera das informações veiculadas e também das informações cotidianas, como constrói uma compreensão dos temas, uma opinião e posição, e deixa as marcas de quem é e de onde está situado social e historicamente no discurso. Privilegiado por ser um espaço discursivo, portanto de discussões, trocas e construções de narrativas cotidianas, assim as cartas de leitores permitem um lugar para que 0 sujeito informacional adentre o campo midiático e o legitime a partir de sua apropriação e leitura interpretativas.

\section{REFERÊNCIAS}

ADGHIRNI, Z.A.; BAESSE, J.M.S. Gêneros opinativos e internet: mais espaço para o leitor. In: CONGRESSO BRASILEIRO DE CIÊNCIAS DA COMUNICAÇÃO, 32., 2009, Curitiba. Anais [...] São Paulo: Intercom, 2009. (01 CD-ROM).

ANDRADE, M.L.C.V.O. Interatividade na correspondência publicada em jornais paulistas. Forma y función, Santafé de Bogotá, D.C., v. 23, n. 2, p. 73-95, 2010. Disponível em: http://www.scielo.org.co/scielo.php?script=sci_arttext\&pid=S0120338X2010000200003\&lng=en\&nrm=iso. Acesso em: 29 maio 2017.

ASSUNÇÃO, A. L. Cartas de Leitores: reescrita e condições de produção de um gênero midiático. In: SIMPÓSIO INTERNACIONAL DE ESTUDOS DE GÊNEROS TEXTUAIS, 4., 2007, Tubarão. Anais [...] Santa Catarina: UNISUL, 2007. p. 662-674. Disponível em:

http://www3.unisul.br/paginas/ensino/pos/linguagem/cd/Port/22.pdf. Acesso em: 15 jan. 2010. 
BAESSE, J. O leitor manifesto: perfil das cartas aos jornais. Comunicação e Espaço Público, Brasília, v. 5, n. 1, p. 73-82, 2005. Disponível em: http://www.fac.unb.br/site/images/stories/Posgraduacao/Revista/Edicoes/20051_revista.pdf. Acesso em: 10 maio 2009.

BORGES, E.V.E. Apropriação da informação: os elementos, o processo e a materialização da informação. 2018. 262f. Tese (Doutorado em Ciência da Informação) - Universidade Estadual Paulista, Marília, 2018.

BORTOLIN, S. Mediação oral da literatura: a voz dos bibliotecários lendo ou narrando. 2010. 232f. Tese (Doutorado em Ciência da Informação) Universidade Estadual Paulista, Marília, 2010.

BRAGA, J. L. Cartas de leitores como dispositivo social crítico. In: CONGRESSO BRASILEIRO DE CIÊNCIAS DA COMUNICAÇÃO, 27, 2004, Porto Alegre. Anais [...] Porto Alegre: ,2004. Disponível em: http://www.portcom.intercom.org.br/pdfs/9623772220619491246136294136647 0002714.pdf. Acesso em: 10 jan. 2013.

CAPURRO, R. Epistemologia e Ciência da Informação. In: ENCONTRO NACIONAL DE PESQUISA EM CIÊNCIA DA INFORMAÇÃO, 5., 2003, Belo Horizonte. Anais [...] Belo Horizonte: Escola de Ciência da Informação da UFMG, 2003.

CHAPARRO. M.C.C. Carta. In: MELO, J.M. (Org.). Gêneros jornalísticos na Folha de S. Paulo. São Paulo: FTD, 1992. p. 63-74,

DAVALLON, J. A mediação: a comunicação em processo?. Prisma.com: Revista de Ciência da Informação e Comunicação do CETAC, Porto, Portugal, n. 4, 2007. Disponível em:

http://ojs.letras.up.pt/index.php/prismacom/article/view/2100/3046. Acesso em: 10 jan. 2009.

DINES, A. O papel do jornal e a profissão de jornalista. 9. ed. São Paulo: Summus, 2009.

ESPÍRITO SANTO, P.; DUMONT, L. M. M. As cartas de leitores e leitoras enviadas a jornais impressos: o que querem informar os assinantes do jornal Estado de Minas. Perspectivas em Ciência da Informação, Belo Horizonte, v.19, n. 2, p. 174-190. 2014. Disponível em:

http://www.scielo.br/scielo.php?script=sci_arttext\&pid=S1413-

99362014000200013\&lng=en\&nrm=iso. Acesso em: 29 maio 2018.

ESPÍRITO SANTO, P.; DUMONT, L. M. M. A leitora e sua relação com o jornal Estado de Minas. Perspectivas em Ciência da Informação, Belo Horizonte, v. 14, n. 3, p. 20-37, 2009. Disponível em: 
http://portaldeperiodicos.eci.ufmg.br/index.php/pci/article/view/507/633. Acesso em: 10 jul. 2010.

ESPÍRITO SANTO, P.; DUMONT, L. M. M. A busca de informação pela mulher nos jornais impressos. In: ENCONTRO NACIONAL DE PESQUISA EM CIÊNCIA DA INFORMAÇÃO, 8., 2007, Salvador. Anais [...] Salvador: ANCIB, 2007. Disponível em: http://www.ancib.org.br/media/dissertacao/GT3--044.pdf. Acesso em: 24 set. 2009.

FONTANINI, I. Cartas ao editor: a linguagem como forma de identificação social e ideológica. In: MEURER, J. L.; MOTTA-ROTH, D. (org.). Gêneros textuais e práticas discursivas: subsídios para o ensino da linguagem. Bauru: Edusc, 2002. p. 225-238.

FREIRE, P. Ação cultural para a liberdade e outros escritos. 14. ed. Rio de Janeiro: Paz e Terra, 2011.

GUARALDO, T. de S. B. Práticas de informação e leitura: mediação e apropriação da informação nas cartas de leitores de um jornal popular do interior de São Paulo. 2013. 239 f. Tese (Doutorado em Ciência da Informação) - Universidade Estadual Paulista Júlio de Mesquita Filho, Faculdade de Filosofia e Ciências de Marília, 2013. Disponível em: http://hdl.handle.net/11449/103356. Acesso em: 20 maio 2014.

ISER, W. O ato da leitura: uma teoria do efeito estético. São Paulo: 34, 1996. v.1.

JEANNERET, Y. A relação entre mediação e uso no campo de pesquisa em informação e comunicação na França. Revista Eletrônica de Comunicação, Informação \& Inovação em Saúde, Rio de Janeiro, v. 3, n. 3, p. 25-34, 2009. Disponível em:

http://www.reciis.icict.fiocruz.br/index.php/reciis/article/view/276/318. Acesso em: 15 jul. 2010.

MAINGUENEAU, D. Introdução à análise do discurso. Curso de Extensão Universitária, 16-20 de maio de 2011, Unesp Assis. Notas de aula.

MAINGUENEAU, D. Análise de textos de comunicação. 2. ed. São Paulo: Cortez, 2002.

MAROCCO, B. Apontamentos sobre a presença do leitor no jornal. UNIrevista, v. 1, n. 3, 2006.

MORIGI, V.J.; ROCHA, C.P.V.; BORGES, M.C. A mediação das cartas dos leitores na mídia: mapas imaginários sobre Porto Alegre. Em Questão, Porto Alegre, v. 16, n. especial, p. 95-108, 2010. Disponível em: http://seer.ufrgs.br/EmQuestao/article/view/15664. Acesso em: 15 fev. 2011. 
MORIGI, V. J. Informação, cultura local e memória social: as cartas dos leitores e a construção dos imaginários sobre Porto Alegre. In: ENCONTRO NACIONAL DE PESQUISA EM CIÊNCIA DA INFORMAÇÃO, 10., João Pessoa, 2009. Anais [...] João Pessoa: ANCIB, 2009.

MARTÍN-BARBERO. J. Dos meios às mediações: comunicação, cultura e hegemonia. 5. ed. Rio de Janeiro: UFRJ, 2008.

ORLANDI, E. Análise de discurso: princípios e procedimentos. 8. ed. Campinas: Pontes, 2009.

ORLANDI, E. Discurso e leitura. 8. ed. São Paulo: Cortez, 2008.

PÊCHEUX, M. A análise de discurso: três épocas (1983). In: GADET, F.; HAK, T. Por uma análise automática do discurso: uma introdução à obra de Michel Pêcheux. 4. ed. Campinas: Unicamp, 2010a. p. 307-315.

PÊCHEUX, M. Ler o arquivo hoje. In: ORLANDI, E. (org.). Gestos de leitura: da história no discurso. 3. ed. Campinas: Unicamp, $2010 \mathrm{~b}$.

RIBEIRO, F. F. A participação dos leitores na imprensa: uma proposta de análise às Cartas do Leitor do Jornal de Notícias. Rev. Comunicação Pública, v. 9, n.15, 2014. Disponível em: http://journals.openedition.org/cp/646. Acesso em: 16 abril 2018.

RUÓTOLO, A.C. Audiência e recepção: perspectivas. Comunicação e Sociedade, São Bernardo do Campo, n. 30, p. 157-170, 1998.

SILVA, M. T. As cartas dos leitores no Público e no Diário de Notícias. Observatorio Journal, v. 2, n. 2, p. 263-279, 2008. Disponível em: http://obs.obercom.pt/index.php/obs/article/view/117. Acesso em: 15 set. 2009.

SILVA, M. T. As "cartas ao director" no jornal Público: um estudo de caso. Biblioteca Online de Ciências da Comunicação, bocc, 2005. Disponível em: http://www.bocc.ubi.pt/_esp/autor.php?codautor=1441. Acesso em: 15 set. 2009.

STIERLE, K. Que significa a recepção dos textos ficcionais? In: LIMA, L.C. (coord.). A literatura e o leitor: textos de estética da recepção. 2. ed. Rio de Janeiro: Paz e Terra, 2002. p. 119-171.

THOMPSON, J.B. A mídia e a modernidade: uma teoria social da mídia. 11. ed. Petrópolis: Vozes, 2009.

ZANOTTI, C. A. Perfis e limites na pró-atividade dos novos sujeitos midiáticos advindos com a internet. Comunicação \& Informação, v. 11, n. 1, p. 67-79, 
2008. Disponível em: https://www.revistas.ufg.br/ci/article/view/22817/13562.

Acesso em: 29 jun. 2018.

ZILBERMAN, R. Estética da recepção e história da literatura. São Paulo: Ática, 2009.

\title{
READER'S LETTERS AS PRIVILEGED SPACES OF APPROPRIATION OF INFORMATION AND THE MEANING EFFECTS
}

\begin{abstract}
Introduction: This study discusses the concept of appropriation of information supported by bibliographic research and critical discussion of works published on the section of letters from readers of printed newspapers. In the following internet databases: Scielo, Google Scholar and BRAPCI portal, in which thirteen scientific papers were selected in Portuguese with the descriptor "reader's letters" and presented data of applied research, relevant to the approach of this study. Objective: To discuss the concept of appropriation of the information supported in the bibliographic study and critical analysis of published works on the readers' letters section. Methodology: Bibliographical research on reader's letters and discussion of the selected articles under the analytical bias of the effects of meaning and elements of discourse analysis. Results: The reader's letters are identified as privileged spaces within the information in newspapers for the studies of information appropriation, since they constitute as a place for the expression of the reader subject and a possible zone of observation for the researchers interested in this thematic, because in the reader's letters it is possible to find the marks of how the reader appropriates the information and the effects of the senses of the reading on him, that is, how he takes the information to his life when he reads. Conclusions: When interacting with the newspaper, texts and other readers, the reader's letters present the appropriation of the information in progress, as they demonstrate how the reader seizes the information conveyed, how he constructs an understanding of the themes, leaving the marks of who he is and where he is socially and historically.
\end{abstract}

Descriptors: Mediation. Reader. Effects of meaning. Discourse analysis. Newspaper.

\section{CARTAS DE LECTORES COMO ESPACIOS PRIVILEGIADOS DE APROPIACIÓN DE LA INFORMACIÓN Y DE LOS EFECTOS DE SENTIDO}

\author{
RESUMEN \\ Introducción: Este estudio analiza el concepto de apropiación de información \\ respaldada por la investigación bibliográfica y la discusión crítica de trabajos publicados
}


en la sección de cartas de lectores de periódicos impresos. En las siguientes bases de datos de Internet: Scielo, Google Scholary el portal BRAPCI, en el que se seleccionaron trece artículos científicos en portugués con el descriptor "cartas de lectores" y que presentaron datos de investigaciones aplicadas, relevantes para el enfoque de este estudio. Objetivo: Discutir el concepto de apropiación de la información apoyado en el estudio bibliográfico y análisis crítico de trabajos publicados sobre la sección cartas de lectores. Metodología: Investigación bibliográfica sobre las cartas de lectores y discusión de los artículos seleccionados bajo el sesgo analítico de los efectos de sentido y elementos del análisis del discurso. Resultados: Se identifican en las investigaciones estudiadas, las cartas de lectores como espacios privilegiados dentro de los medios de información impresos para los estudios de apropiación de la información, ya que se constituyen como lugar de la expresión del sujeto lector y posible zona de observación de los investigadores interesados en esa investigación en las cartas es posible encontrar las marcas de cómo el lector se apropia de la información y los efectos de sentidos de la lectura sobre él, o sea, cómo lleva la información para su vida cuando lee. Conclusiones: Al interactuar con el periódico, con los textos y los demás lectores, las cartas de lectores presentan la apropiación de la información en curso, pues demuestran cómo el lector se apodera de las informaciones vehiculadas, como construye una comprensión de los temas, dejando las marcas de quien es y de donde está situado social e históricamente.

Descriptores: Mediación. Lector. Efectos de sentido. Análisis del discurso. Periódico.

Recebido em: 20/02/2019

Aceito em: 07/02/2020 